\title{
Social networks and the geography of entrepreneurship
}

\author{
Olav Sorenson
}

Published online: 5 July 2018

(C) The Author(s) 2018

\begin{abstract}
Social relationships play at least three important roles in entrepreneurship. They help to determine who sees entrepreneurship as an available and desirable career path. Entrepreneurs use their contacts to raise funds for and to recruit employees and partners to their ventures. Social relationships also influence where and when entrepreneurs want to spend their leisure time. Because of these factors, entrepreneurs tend to found their firms in the places that they live (and in the industries in which they have been employed). That, in turn, implies that industries will tend to become and remain concentrated in a small number of places, even when firms do not benefit from this clustering.
\end{abstract}

Keywords Agglomeration - Clusters · Economic geography $\cdot$ Entrepreneurship $\cdot$ Social networks

JEL Classification $\mathrm{L} 26 \cdot \mathrm{L} 14 \cdot \mathrm{R} 1$

\section{Introduction}

My route into entrepreneurship as an area of research began with an interest in economic geography. One of the classic questions in economic geography has been:

O. Sorenson $(\square)$

Yale School of Management, New Haven, CT, USA

e-mail: olav.sorenson@yale.edu
Why do firms locate where they do? More specifically, why do firms of particular types tend to cluster together in space?

In attempting to answer this question, a long and storied literature in economic geography has painted a picture in which managers and entrepreneurs-when deciding where to locate a headquarters, a factory, a retail outlet, or some other sort of site-consider all of the possible locations available to them and then choose the ones that maximize the sales or profitability of their enterprises. Early writings in economic geography therefore emphasized, as explanations for geographic clustering, the importance of being near to customers or to natural resources that served as critical inputs in production (e.g., von Thunen (1966), Weber (1928), and Isard (1949)) — such as coal and iron ore for heavy manufacturing (Harris 1954).

Two aspects of this picture-two assumptions in these theories-have long seemed problematic to me. The first concerns the level of calculation accorded to the actors choosing locations. For some situations and for some industries, substantial time and effort goes into these choices. Large retailers and manufacturers, like Amazon, BMW, and WalMart, invest substantial resources into determining just where they should locate their plants, their stores, and their storage facilities. They almost certainly do try to choose locations that minimize their transportation costs for materials and finished goods and that allow them to serve as many customers as possible. 
But entrepreneurs do not have the time, the information, or the resources that one would seem to need to choose optimal locations. How then do they decide where to locate their ventures?

One possibility is that they do not decide. When doing research for one of my first projects on the geography of entrepreneurship, I interviewed a series of entrepreneurs to learn more about how they thought about this question. I still recall one of my first meetings. When asked why he located his business where he did, the entrepreneur responded "Because my wife didn't want a mess in the kitchen." In other words, when asked about his choice of location, the entrepreneur thought that I had meant why did he choose his garage instead of some other part of his house, rather than why he chose Silicon Valley instead of some other region. When pressed further, it became clear that he had never considered another place. He had just started his business where he had been living. That absence of explicit choice probably represents a common route for entrepreneurs.

But another possibility is that entrepreneurs do consider alternative locations. They just consider fewer of them and they may only evaluate these potential places through their intuition or even at a subconscious level, through a gut feel. The question then becomes whether these limited choice processes approximate the outcomes predicted by theories that assume that entrepreneurs consider locations far and wide. That is, do entrepreneurs behave "as if" they chose locations to maximize the profitability of their businesses?

That question brings me to the second problematic assumption. Theories of location choice have usually treated entrepreneurs and their firms as being homogeneous-identical in their abilities, in their resources, and in their interests. But entrepreneurs vary on many dimensions. They have different desires for what they hope to get out of their ventures-many want autonomy, some seek more leisure time, a few hope to get rich. They also bring different abilities and resources to bear. Most, for example, have prior experience in the industries that they enter. Some have been managers before. They also vary in terms of their levels of wealth and in the depth of their social capital.

Much of my research has been focused on trying to paint a more realistic portrait of the entrepreneur, particularly in terms of how their social networks - their social relationships with others-enable and constrain their ability to found firms and to succeed in these enterprises, and particularly with respect to the question of where they locate their startups. In other words, how do social networks influence the geography of entrepreneurship and the geographic distributions of industries?

\section{Three relational mechanisms}

Social relationships influence entrepreneurs and their choices in at least three important ways. The first concerns deciding whether or not they should become entrepreneurs in the first place. The second relates to their ability to build effective organizations - to raise capital, to hire employees, to secure suppliers, and to attract customers. The third, meanwhile, has to do with their outside interests. Let me discuss each of these mechanisms in turn.

\subsection{Determining appropriateness}

One of the first papers that I wrote examined the entry of entrepreneurs in the shoe industry in the USA (Sorenson and Audia 2000). As part of my research, I read every biography that I could find written about someone who had founded a shoe company. There were more than twenty. Some of these books had almost certainly been funded by the founders themselves and had been exercises in vanity but they provided useful information nonetheless on the backgrounds of these founders. Interestingly, nearly every one of the entrepreneurs described in these biographies had been employed in footwear manufacturing prior to founding their firms, usually as the manager of a plant or as the head of a production line. In nearly every case, the biography would also describe some eureka moment when the future entrepreneur decided that he could start his own company. Usually, the precipitating event described involved seeing someone else, often the manager of another plant, sometimes at a rival company, starting their own firm (e.g., Nunn 1953).

Seeing others, particularly those who one knows and perceives as similar to oneself, engaged in entrepreneurship encourages people to become entrepreneurs themselves for at least three reasons. First, it influences individuals' beliefs about their ability to run a business on their own. There is often a 
sense of "If he [or she] can do it, so can I." (Sorenson and Audia 2000; Bosma et al. 2012).

Second, entry serves as a signal of the attractiveness of starting a business of a particular type (Sørensen and Sorenson 2003). If one believes that entrepreneurs choose to enter an industry because they see promise there, then entry-particularly the entry of many entrepreneurs in an industry in a short span of time-should lead to a perception that opportunities abound. Seeing other become entrepreneurs can therefore raise the expectations that potential entrepreneurs have for the probable profitability of founding a firm.

Third, having a number of entrepreneurs among one's family, friends, and acquaintances also legitimates this path as a career choice (Etzioni 1987; Stuart and Ding 2006). In many communities and social circles, founding a firm has a social cost, in the sense that it does not have the same prestige accorded to it as does being a professional or being an employee in a reputable firm. It may even have a stigma associated with it - the person could not find employment. However, as more entrepreneurs enter a person's social sphere, founding a firm becomes seen as normal, even desirable (Sorenson 2017). The social costs of becoming an entrepreneur decline (Etzioni 1987).

Consistent with these three factors, studies across a variety of settings have found that being connected to entrepreneurs and former entrepreneurs increases the odds that individuals attempt to start their own businesses. Sørensen (2007), for example, reported that the children of entrepreneurs become entrepreneurs at much higher rates than one would expect based on their individual characteristics. Stuart and Ding (2006) and Nanda and Sørensen (2010) found that those working with colleagues who had founded firms in the past more frequently became entrepreneurs in the future. Falck et al. (2010) and Kacperczyk (2013) reported similar results for those who had gone to high school and college with people who later became entrepreneurs. Andersson and Larsson (2016) found that having entrepreneurs as neighbors also increases the odds of an individual becoming an entrepreneur. Most recently, in a field experiment with random assignment to being connected to an entrepreneur, Easley and Wang (2017) reported that students who had entrepreneurs as mentors more frequently became founders themselves. Whether or not individuals have social connections to entrepreneurs crucially determines whether they will attempt to become entrepreneurs themselves.

\subsection{Acquiring resources}

Once entrepreneurs have decided to start their businesses, their ability to access a variety of resources then affects their odds of success. They must raise capital, recruit employees, and secure suppliers. Social relationships again prove critical to this process.

Social connections, for example, influence the amount of financial capital that entrepreneurs can raise. Those studying entrepreneurship have long understood that family and friends (and fools) provide much of the earliest funding for startups (Bygrave et al. 2003; Ruef 2010). Some may believe that crowdfunding will reduce the importance of these close connections in the future. But even in crowdfunding campaigns, family and friends appear crucial to getting the process going, providing the first donations and investments that precipitate cascades of interest from strangers (Mollick 2014; Agrawal et al. 2015).

The reasons underlying the importance of family and friends to the early financing of startups are at least threefold. First, any new venture involves a great deal of uncertainty, not just about the enterprise but also about the entrepreneur as a manager. Those who know the entrepreneurs best have the most information about whether they can pull it off, whether they will succeed. If those best able to evaluate the entrepreneurs are reluctant to put their own money into a venture, that also signals to others that the startup has below average odds of success.

But family and friends may also provide financial capital for more subjective reasons. On the one hand, family and friends may well have favorable opinions of the entrepreneur, believing the person to be more able and their ideas more promising than an objective outsider would (Sorenson and Waguespack 2006). Those close to the entrepreneur would then have greater (false) confidence in the entrepreneur, leading them to invest, not fully appreciating the possible downsides.

On the other hand, even if family and friends recognize that the entrepreneur and the idea seem to be long shots, they might still invest simply because they derive satisfaction from supporting their loved ones. Note that many family and friends loan money 
to entrepreneurs without even charging them interest (Bygrave and Reynolds 2006; Bygrave and Hunt 2008). Regardless of the reasons for them, these early investments provide critical funding for the first days of a startup, when it faces the most uncertainty.

Professional investors, interestingly, exhibit similar patterns. Venture capitalists, for example, rarely fund entrepreneurs with whom they do not have a prior direct or indirect relationship (Shane and Stuart 2002; Shane and Cable 2002). In part, this probably reflects the fact that venture capitalists can gather information-do due diligence-more effectively on entrepreneurs with whom they share a connection (Sorenson and Stuart 2001). In part, it stems from the fact that they can also more easily advise and monitor these companies after they have invested in them (Sorenson and Stuart 2001; Bernstein et al. 2016). But it may also arise from biases on the part of these investors, the fact that they likely have elevated opinions of their friends and acquaintances and their ideas and therefore that they invest in them more readily than they should. Indeed, recent studies have reported that when venture capitalists invest in others with whom they share a connection, they experience lower returns (e.g., Bengtsson and Hsu 2015; Gompers et al. 2016).

As difficult as it can be to raise capital, recruiting employees can prove even more daunting. Whereas investors can diversify away some of the risks associated with investing in any particular startup, employees must usually commit to a single firm (Sorenson 2003). Adding to the difficulty of recruiting, the best employees already have jobs. Entrepreneurs therefore cannot rely on hiring only from those who apply for a position. They must lure individuals with secure jobs away from their current employers.

Convincing employees to join startups therefore often depends on someone on the founding team having a strong connection to the person, perhaps as a long-time friend or as a trusted former colleague from a prior employer (Ruef et al. 2003; Ruef 2010). The motivation for these friends (and family) to join startups as employees, to a large extent, parallels the reasons for them to invest in these firms. Because of their existing relationships, they have more favorable beliefs about the prospects of these entrepreneurs and their ventures. But they may also find tempting the prospect of spending time on a day-to-day basis with people whose company they enjoy.
The quality of these early employees nevertheless ends up being critical to the success of startups. These individuals help to establish the routines for these firms, the roles within them, and the culture of the organization (Burton and Beckman 2007; Beckman and Burton 2008; Dahl and Klepper 2015). Founders with more extensive social networks, particularly in the industries they enter, will therefore tend to recruit more qualified employees who will, in turn, raise the odds that their firms prosper (Dahl and Sorenson 2014).

Although less has been written on other dimensions of the founding process, the importance of social connections to entrepreneurs probably extends to their ability to access a variety of other resources as well. For example, finding suppliers and distributors, particularly ones that allow for more flexible contracts, may depend on the strength of the social relationships between the entrepreneur and the owners of those businesses (Uzzi 1996). The first customers, those willing to give the entrepreneur a try, also probably come disproportionately from the ranks of those with social connections to the entrepreneur (i.e., family and friends). The breadth and depth of entrepreneurs' social networks therefore largely determine who among them will succeed.

\subsection{As amenities}

One might see the first two roles of relationships as functional but social relationships also play another important role here: they contribute to satisfaction with life. People enjoy spending time with family and friends. The potential to spend more time with them will therefore often influence the choices of entrepreneurs - of what types of businesses to start, of whom to hire, and of where to locate (Gimeno et al. 1997; Dahl and Sorenson 2009).

An interesting recent study illustrated the importance of these social relationships to happiness by studying the emotional well-being of people across the days of the week. Using survey data where people reported, on a daily basis, the extent to which they had experienced positive and negative emotions, the researchers found that people generally had higher levels of positive emotions and lower levels of negative emotions on the weekend (Young and Lim 2014). That, in itself, seems unsurprising. One might expect that people would prefer the weekends to work. But 
they found exactly the same pattern for those without jobs. Even the unemployed preferred the weekend. Why? Because even though the unemployed had free time from Monday to Friday, they had few family and friends with whom they could share this leisure time.

People will give up a lot in terms of prospective income in exchange for time with family and friends. To get a sense of how much people value these relationships, Michael Dahl and I looked at the location choices of individuals as a form of revealed preference. People can often earn more by moving to a job in another region, usually because that place has opportunities better suited to the person's education or experience (Hicks 1932; Davies et al. 2001). But the places with the best jobs may not be where friends and relatives live. That fact allowed us to estimate how much potential income people would forgo to live closer to their loved ones.

It will not surprise anyone that people have a preference for being near family and friends. But the size of these preferences might surprise you. For example, we found that blue collar workers in Denmark, on average, appeared to value a job that would require them to live twice as far away from their siblings equal to a closer one that paid $\$ 1,400$ less per year-about $4 \%$ of the average income (Dahl and Sorenson 2010b). Technical workers, such as engineers and medical doctors, placed even greater value on proximity to family and friends, at least in absolute terms (Dahl and Sorenson 2010a). The average technical worker appeared to equate a doubling in the distance to siblings to a $\$ 2,400$ difference in income (again, about $4 \%$ of average annual earnings). Potential earnings, in fact, proved less important to location choice than the proximity of a place to their current home and to the past places that they had lived, as well as to the proximity of a place to parents and to former high school and college classmates (Dahl and Sorenson 2010a; 2010b).

Entrepreneurs are not any different in these preferences from employees except that they have more control over when and where they work. Figueiredo et al. (2002), for example, estimated that the typical entrepreneur in Portugal would forgo tens of thousands of dollars in potential cost savings to remain in their home regions. More broadly, in determining the choice of where to locate their ventures, attributes related to the attractiveness of opening a particular sort of business in a particular place explained less than $20 \%$ of the variance in where entrepreneurs chose to open their businesses (Dahl and Sorenson 2009). By contrast, proximity to family, friends, and places where they had lived before, could account for more than $60 \%$ of this variance (Dahl and Sorenson 2009). Surveys similarly find that between half and two-thirds of entrepreneurs attribute their choice of location to personal factors (e.g., Katona and Morgan 1952; Mueller and Morgan 1962).

\section{The geography of social networks}

Family, friends, and acquaintances matter to who founds firms, to who succeeds, and to where entrepreneurs want to live. But saying that these relationships matter does not connect them to a particular place. To connect social relationships to geography, one must recognize that people tend to interact primarily with those who live in close proximity to them.

Two factors account for the local nature of these relationships. The first has to do with the opportunities to meet people. We usually meet people through the course of our daily activities - going to work, shopping, bringing kids to school, going to church, playing in a sports league. These activities are almost always highly local, bringing people no more than a few miles (kilometers) from their homes. As a result, the people that we meet typically live near us.

The second factor concerns the cost of continuing the relationship. Maintaining a relationship, even with a casual acquaintance, generally requires some regular contact. That might mean seeing the person by happenstance every few weeks or months. Or it might involve arranging a meeting-coffee or lunch. In either case, the ease of developing and maintaining these relationships depends on proximity. The odds of running into someone regularly by chance requires them to travel to the same places at the same times of day on a regular basis. The travel time-and therefore the costassociated with arranged in-person meetings also increases with distance (Stouffer 1940), though not as rapidly. While the travel costs for arranged meetings increase on a roughly linear basis with distance, the odds of chance encounters decrease as a function of the square of the distance between the two individuals. 
Empirically, at every spatial scale and for nearly every sort of relationship, the probability of a social connection has been found to decline with distance (Rivera et al. 2010). Early studies in sociology, for example, examined marriage and found that people tended to marry those who lived in a radius of a few city blocks from their home (Bossard 1932; Davie and Reeves 1939). Students in dormitories and employees in offices most frequently interact with and become friends with those in the neighboring rooms (Festinger et al. 1950; Allen 1977; Marmaros and Sacerdote 2006; Kleinbaum et al. 2013). Surveys of people's friends find them heavily concentrated in the cities in which they live (Lansing and Mueller 1967; Rivera et al. 2010).

Social connections tend to exist locally not just in physical space but also in social space. Individuals therefore tend to have relationships with others similar to them-of the same religion and ethnicity, of the same level of education, with experience in the same firms and industries (Marsden 1988; McPherson et al. 2001). The same processes account for the importance of proximity in social space. Those in the same demographic categories and those of similar backgrounds tend to have the same interests and to belong to the same organizations (Blau 1977). These activities and organizations act as social focal points that provide opportunities for these individuals to meet and to interact (Feld 1981). For entrepreneurs, these processes mean that their social networks will connect them most strongly to the places where they have lived the longest and most recently and to those in the industries in which they have worked.

\section{Implications for entrepreneurs}

At the level of the entrepreneur, the most direct implication of these factors is that entrepreneurs will tend to locate their businesses in the places that they have been living (and will enter industries in which they have worked). In other words, they will rarely move elsewhere in search of some optimal place. Part of that geographic inertia stems from their interest in remaining near family and friends. They would therefore willingly pay a price for it - a compensating differential in earnings.

But the importance of social networks to accessing resources also means that staying in the places that they have lived will also generally maximize their odds of success. So, interestingly, those most concerned with the success of their businesses should also remain rooted in place.

Several studies have now documented that entrepreneurs tend not to move. Michelacci and Silva (2007), for example, in a cross-sectional analysis of data from Italy and from the USA found that entrepreneurs in both countries more commonly lived in the places in which they had been born. That result, of course, could stem from survival bias. If local entrepreneurs have an advantage in terms of the performance of their ventures, then their businesses might also survive longer meaning that these local entrepreneurs would end up overrepresented in any cross section.

But in a prospective design that followed entrepreneurs from the moment that they founded their firms, Michael Dahl and I found similar results (Dahl and Sorenson 2009). Danish entrepreneurs appeared most likely to start their ventures in places close to where they had been living and working. If they moved, they would most commonly return to a place that they had lived before. Larsson et al. (2017) recently reported similar results for recent graduates in Sweden, who tend to start businesses in the regions in which they have gone to school or in their hometowns.

Entrepreneurs who had lived in a region longer also appeared more successful on nearly every dimension (Dahl and Sorenson 2012). Their firms survived longer. They grew faster in terms of sales and numbers of employees. And they earned more profits. Overall, tenure in the region appeared roughly as important as experience in the industry to the success of the entrepreneur. Those results held, moreover, even when using the location of parents as an instrument for the extent to which entrepreneurs had experience in the region-to eliminate any selection effects associated with entrepreneurs remaining in those regions precisely because they had stronger business connections in them. Michelacci and Silva (2007) similarly found that local-born entrepreneurs in Italy and the USA had businesses with more and better paid employees and with more capital investment.

Many have suggested that the movement of highprofile companies to Silicon Valley serves as a counter example to the idea that entrepreneurs do best in their home regions. Facebook, for example, moved from 
Cambridge to California, Palo Alto to be exact. But not only do these companies represent the survivorsthe exceptions if you will-but also they often fit within the broader story of the importance of social connections. Many of these migrant firms already had the support of a prominent venture capitalist or angel investor from Silicon Valley before they moved. Facebook had Peter Thiel on board. These active investors have extensive local networks developed over decades. When they fund a company, they often lend their social capital to these entrepreneurs, helping them to connect with other investors and to recruit able early employees and executives.

The other group that has sometimes been presented as an exception has been immigrants. Although immigrants have higher levels of entrepreneurship than the population as a whole (Borjas 1995), people rarely move to another country with the goal of founding a firm. Instead, they move for education, employment in an existing firm, or perhaps to escape poverty or persecution at home.

But the fact that immigrants - and even within country migrants - have one foot in their old location and another in the new one potentially presents them with interesting opportunities. It might mean, for example, that they have the know-how needed to bring a new industry to the region. The shoe cluster around St. Louis, for example, arose when German immigrants who had been involved in footwear production in Germany moved to Missouri and began opening companies there (Clark 1928). Or, the opportunity might stem from return migration. Someone from Israel, for example, might move to Silicon Valley to get a degree at Berkeley and stay in the USA to work in a semiconductor firm. After gaining experience in the industry, he might return home and found a firm there. Indeed, Dov Frohman followed a path not too far from that one, except that he convinced Intel to open a subsidiary in Israel (rather than founding his own firm). Several employees of that subsidiary ended up being the entrepreneurs who built the semiconductor cluster in Israel.

From a policy perspective, however, the importance of social relationships to successful entrepreneurship means that regions interested in promoting startups would probably do best to nurture their own residents. Programs to attract entrepreneurs from elsewhere-such as the Start-Up Chile program-may bring talented individuals to a region. But without local connections, they will find it difficult to assemble the resources needed to succeed. Without being embedded in the community, moreover, even those who do succeed may return home, potentially taking their ventures and any jobs that they created with them. A more fruitful approach would involve ensuring that the region has an infrastructure for supporting local entrepreneurs: sources of capital, mentoring, and support services that reduce the cost of getting started.

But the exposure effects, seeding the idea that entrepreneurship might represent an attractive and legitimate career path remains an issue. How does a community that has had few entrepreneurs-that has few role models available-convince its residents to engage in entrepreneurship? There, an interesting field experiment from Stanford suggests a path forward. Students assigned entrepreneurs as mentors became entrepreneurs themselves at higher rates (Easley and Wang 2017). In other words, even randomly assigned relationships and ones developed in a short period of time still led to these exposure effects. Regions therefore might consider ways to import former entrepreneurs from other places-at least temporarily — as a means of providing entrepreneurial role models to their residents.

\section{Implications for industries and regions}

The implications for industries seem even more interesting. Many providers of goods and services where the customer usually travels to the provider, think of businesses such as bars and retailing, end up being distributed fairly evenly according to the population. They may cluster on high streets or in malls but customers will only travel so far to go to them so they end up being everywhere.

But the manufacturers and providers of goods and services that get delivered to the customer can locate their production almost anywhere. Yet, study after study has found that these industries tend to cluster in particular cities or regions (Porter 1990; Krugman 1991). Think about the film industry in Los Angeles, mechanical watch manufacturers in Geneva, or automobile production in Detroit.

Given that most of these industries do not rely on any heavy or difficult-to-transport inputs, the usual interpretation has been that these clusters must result from economies of agglomeration (Marshall 1922; 
Romer 1986; Krugman 1991). In other words, firms in these industries must benefit from locating near their competition. That may allow them, for example, to share specialized suppliers (Piore and Sabel 1984; Porter 2000). In Los Angeles, for example, one can find a wide array of unusual services, such as prop rentals for film production. Or, it might allow them to share the costs of innovation and to adopt innovations more rapidly (Romer 1986; Saxenian 1994; Audretsch and Feldman 1996).

But the fact that social relationships play so many important roles for entrepreneurs means that one would expect industries to cluster even in the absence of agglomeration externalities. The most successful entrepreneurs usually have prior experience in an industry, meaning that they have been employed at an incumbent in the industry. As noted previously, entrepreneurs will also tend to stay in the places that they live when founding their firms. The combination of these two facts means that entrepreneurs in an industry will disproportionately emerge in the same regions in which one finds existing firms in that industry. It's a sort of spin-off process. Even if firms do not benefit from being near their competitors, clusters of firms will tend to form.

Perhaps the critical test in determining whether clustering stems from economies of agglomeration or whether it emerges from this spin-off process involves examining the performance of firms in these concentrated clusters relative to those located in regions more remote from their competitors (Appold 1995; Sorenson and Audia 2000). Surprisingly, few studies, however, have examined this question directly. The more common approach to estimating empirically whether economies of agglomeration exist has been to estimate entry or employment growth as a function of industry concentration (e.g., Rosenthal and Strange2003; Delgado et al. 2010). But the spin-off process described here would also generate correlations between concentration and both entry and employment growth, even though companies in these industry clusters might not perform particularly well and even though regions overall may not benefit from this industrial concentration.

I first examined this question in the shoe industry in the USA (Sorenson and Audia 2000). It clusters in three main places, one around Boston; another around Milwaukee, WI; and a third in St. Louis, MO. Plants located close to their competitors failed at much higher rates than those in more isolated locations. The most concentrated places had failure rates nearly triple those of the least concentrated ones. If entry occurred at random across the USA, the industry would diffuse quickly. But, because entrepreneurship in the industry concentrated even more heavily in the places that already had a large number of shoe companies, the industry has remained highly clustered.

I next considered the same question in biotechnology, one of the high technology industries that people have often pointed to as an example of economies of agglomeration (e.g., Audretsch and Stephan 1996). In the USA, biotechnology has become concentrated in Cambridge, San Diego, and South San Francisco. Interestingly, biotechnology exhibits very similar patterns (Stuart and Sorenson 2003). Biotechnology companies located further away from other biotechnology companies had the highest rates of success, in terms of the probability of being acquired or of going public. But entry continued to occur at the highest rates in the most concentrated regions, which offered the lowest odds of success.

This general pattern has been found in other industries as well. Appold (1995), for example, found that metalworking plants located in clusters performed worse than those in places less densely populated with metalworking manufacturers. Sorenson (2005) found the same patterns in the computer industry. Buenstorf and Klepper (2009) similarly argue that the Akron tire cluster arose from spin-off processes rather than due to economies of agglomeration. These processes may indeed affect almost all industries. Glaeser et al. (1992), for example, found that, on average, cities with more concentrated employment shares in particular industries grow more slowly than those with more diversified economies.

Of course, economies of agglomeration may arise in some industries. They may even exist to some extent in the industries highlighted above (cf. Glaeser 1992). The negative effects of competition in the labor market and in the jockeying for business partners may simply outweigh any positive spillovers at the firm level. But the fact that firms do not benefit from co-location should lead us to be much more skeptical about whether such externalities exist and whether clusters represent the optimal geographic distribution of industries from a societal point of view. 
These findings therefore raise important issues for public policy. In the hope of becoming the next Silicon Valley, a large number of places around the world have introduced programs for encouraging entrepreneurship in particular industries. But the fact that spin-off processes play such a prominent role in the emergence and persistence of clusters points to another potential route to becoming Silicon Valley, or at least to effective economic development. Instead of trying to encourage entrepreneurship in an industry, regions might instead recruit a large incumbent in the industry to locate a plant or facility in them. Some of the employees hired by these incumbents might then become entrepreneurs for a generation of local startups in the industry.

Just such a process of the entry of an established firm and the subsequent spin-off of entrepreneurs in the industry appears to account for the emergence of many clusters. One can trace the Israeli semiconductor cluster to the entry of Intel in the region. The Bangladesh garment cluster similarly appears to have spawned from foreign manufacturers that had moved to the country (Moustafa and Klepper 2017). Across a variety of industries, Greenstone et al. (2010) found that subsidies to lure large manufacturers to a region paid for themselves, in large part because they led to the entry of many additional firms in the industry. Although they could not trace the origins of the entrepreneurs behind these businesses, the entrants probably came from these plants, emerging from the same spin-off processes seen elsewhere.

But the fact that clusters can exist and persist even in the absence of agglomeration externalities means that policymakers should exercise caution in their attempts to build clusters. The value of encouraging concentration relies on the idea that these spillovers promote economic growth. Much as one would find in a portfolio of financial assets, industry concentration in a region increases risk. If a downturn or technological innovation has a negative effect on an industry, it will affect many employers within the region. Those laid off may not have any local employment options. Detroit, the Silicon Valley of the beginning of the 20th century, has become a near wasteland as the American automobile industry has declined. In the absence of economies of agglomeration, one should prefer to have more diversified industrial bases. In contrast to Detroit, Los Angeles, a highly diversified region, has weathered many changes in the economic winds.
Acknowledgements Let me first thank my wife, Constança Esteves-Sorenson, for her unwavering support and for constantly serving as a sounding board. I would also like to thank my many coauthors, especially Michael S. Dahl, Lee Fleming, Sampsa Samila, Toby Stuart, and Jesper Sørensen. Without them, none of the papers discussed here would have been as good and many of them might never have been written.

Open Access This article is distributed under the terms of the Creative Commons Attribution 4.0 International License (http:// creativecommons.org/licenses/by/4.0/), which permits unrestricted use, distribution, and reproduction in any medium, provided you give appropriate credit to the original author(s) and the source, provide a link to the Creative Commons license, and indicate if changes were made.

\section{References}

Agrawal, A., Catalini, C., Goldfarb, A. (2015). Crowdfunding: geography, social networks, and the timing of investment decisions. Journal of Economics and Management Strategy, 24(2), 253-274.

Allen, T.J. (1977). Managing the flow of technology: technology transfer and the dissemination of technical information within the R\&D organization. Cambridge: MIT Press.

Andersson, M., \& Larsson, J.P. (2016). Local entrepreneurship clusters in cities. Journal of Economic Geography, 1(1), 39-66.

Appold, S. (1995). Agglomeration, interorganizational networks and competititve performance in the U.S. metalworking sector. Economic Geography, 71(1), 27-54.

Audretsch, D.B., \& Feldman, M. (1996). R\&D spillovers and the geography of innovation and production. American Economic Review, 86(3), 630-640.

Audretsch, D.B., \& Stephan, P.E. (1996). Company-scientist locational links: the case of biotechnology. American Economic Review, 86(3), 641-652.

Beckman, C.M., \& Burton, M.D. (2008). Founding the future: path dependence in the evolution of top management teams from founding to IPO. Organization Science, 19(1), 3-24.

Bengtsson, O., \& Hsu, D.H. (2015). Ethnic matching in the U.S. venture capital market. Journal of Business Venturing, 30(2), 338-354.

Bernstein, S., Giroud, X., Townsend, R. (2016). The impact of venture capital monitoring. Journal of Finance, 71(4), 1591-1622.

Blau, P.M. (1977). Inequality and heterogeneity. New York: Free Press.

Borjas, G. (1995). The economics of immigration. Journal of Economic Literature, 32(4), 1667-1717.

Bosma, N., Hessels, J., Schutjens, V., Praag, M.V., Verheul, I. (2012). Entrepreneurship and role models. Journal of Economic Psychology, 33(2), 410-424.

Bossard, J.S. (1932). Residential propinquity as a factor in marriage selection. American Journal of Sociology, 38(2), 219-224. 
Buenstorf, G., \& Klepper, S. (2009). Heritage and agglomeration: the Akron tyre cluster revisited. Economic Journal, 119, 705-733.

Burton, M.D., \& Beckman, C.M. (2007). Leaving a legacy: position imprints and successor turnover in young firms. American Sociological Review, 72(2), 239-266.

Bygrave, W.D., Hay, M., Ng, E., Reynolds, P.D. (2003). Executive forum: a study of informal investing in 29 nations composing the Global Entrepreneurship Monitor. Venture Capital, 5(2), 101-116.

Bygrave, W.D., \& Hunt, S. (2008). For love or money? A study of financial returns on informal investments in businesses owned by relatives, friends, and strangers. Babson College Center for Entrepreneurship Research Working Paper No. 2008-09.

Bygrave, W.D., \& Reynolds, P.D. (2006). Who Finances Startups in the USA? A Comprehensive Study of Informal Investors. Babson Kauffman Entrepreneurship Research Conference.

Clark, V.S. (1928). History of manufacturers in the United States, 1860-1914. Washington: Carnegie institute.

Dahl, M.S., \& Klepper, S. (2015). Whom do new firms hire? Industrial and Corporate Change, 24(4), 819-836.

Dahl, M.S., \& Sorenson, O. (2009). The embedded entrepreneur. European Management Review, 6(3), 172-181.

Dahl, M.S., \& Sorenson, O. (2010a). The migration of technical workers. Journal of Urban Economics, 67(1), 33-45.

Dahl, M.S., \& Sorenson, O. (2010b). The social attachment to place. Social Forces, 89(2), 633-658.

Dahl, M.S., \& Sorenson, O. (2012). Home sweet home? Entrepreneurs location choices and the performance of their ventures. Management Science, 58(6), 1059-1071.

Dahl, M.S., \& Sorenson, O. (2014). The who, why and how of spinoffs. Industrial and Corporate Change, 23(1), 661-688.

Davie, M.R., \& Reeves, R.J. (1939). Propinquity of residence before marriage. American Journal of Sociology, 44(4), 510-517.

Davies, P.S., Greenwood, M.J., Li, H. (2001). A conditional logit approach to U.S. state-to-state migration. Journal of Regional Science, 41(2), 337-360.

Delgado, M., Porter, M.E., Stern, S. (2010). Clusters and entrepreneurship. Journal of Economic Geography, 10(4), 495-518.

Easley, C., \& Wang, Y. (2017). Social influence in career choice: evidence from a randomized field experiment on entrepreneurial mentorship. Research Policy, 46(3), 636-650.

Etzioni, A. (1987). Entrepreneurship, adaptation and legitimation: a macro-behavioral perspective. Journal of Economic Behavior \& Organization, 8(2), 175-189.

Falck, O., Heblich, S., Luedemann, E. (2010). Identity and entrepreneurship: do school peers shape entrepreneurial intentions? Small Business Economics, 39(1), 39-59.

Feld, S.L. (1981). The focused organization of social ties. American Journal of Sociology, 86(5), 1015-1035.

Festinger, L., Schacter, S., Back, K.W. (1950). Social pressure in informal groups. New York: Harper.

Figueiredo, O., Guimaraes, P., Woodward, D. (2002). Homefield advantage: location decisions of Portuguese entrepreneurs. Journal of Urban Economics, 52(2), 341-361.
Gimeno, J., Folta, T.B., Cooper, A.C., Woo, C.Y. (1997). Survival of the fittest? Entrepreneurial human capital and the persistence of underperforming firms. Administrative Science Quarterly, 42(4), 750-783.

Glaeser, E.L., Kallal, H.D., Scheinkman, J.A., Shleifer, A. (1992). Growth in cities. Journal of Political Economy, 100(6), 1126-1152.

Gompers, P.A., Mukharlyamov, V., Xuan, Y. (2016). The cost of friendship. Journal of Financial Economics, 119(3), 626644.

Greenstone, M., Hornbeck, R., Moretti, E. (2010). Identifying agglomeration spillovers: evidence from winners and losers of large plant openings. Journal of Political Economy, 118(3), 536-598.

Harris, C.D. (1954). The market as a factor in the location of industry in the United States. Annals of the Association of American Geographers, 44(4), 315-348.

Hicks, J.R. (1932). The theory of wages. London: MacMillan.

Isard, W. (1949). A general theory of location and spaceeconomy. Quarterly Journal of Economics, 41, 629-658.

Kacperczyk, A.J. (2013). Social influence and entrepreneurship: the effect of university peers on entrepreneurial entry. Organization Science, 24(3), 664-683.

Katona, G., \& Morgan, J.N. (1952). The quantitative study of factors determining business decisions. Quarterly Journal of Economics, 66(1), 67-90.

Kleinbaum, A.M., Stuart, T.E., Tushman, M.L. (2013). Discretion within constraint: homophily and structure in a formal organization. Organization Science, 24(5), 1316-1336.

Krugman, P. (1991). Geography and trade. Cambridge: MIT Press.

Lansing, J.B., \& Mueller, E. (1967). The geographic mobility of labor. Ann Arbor: Institute for Social Research.

Larsson, J.P., Wennberg, K., Wiklund, J., Wright, M. (2017). Location choices of graduate entrepreneurs. Research Policy, 46(8), 1490-1504.

Marmaros, D., \& Sacerdote, B. (2006). How do friendships form? Quarterly Journal of Economics, 121(1), 79-119.

Marsden, P.V. (1988). Homogeneity in confiding relations. Social Networks, 10, 57-76.

Marshall, A. (1922). Principles of economics, 8th edn. London: MacMillan.

McPherson, J.M., Smith-Lovin, L., Cook, J.M. (2001). Birds of a feather flock together: homophily in social networks. Annual Review of Sociology, 27, 415-444.

Michelacci, C., \& Silva, O. (2007). Why so many local entrepreneurs? Review of Economics and Statistics, 89(4), 615-633.

Mollick, E. (2014). The dynamics of crowdfunding: an exploratory study. Journal of Business Venturing, 29(1), 1-16.

Moustafa, R., \& Klepper, S. (2017). Industrial knowledge development through tacit knowledge seeding: evidence from the Bangladesh garment industry. Management Science, 64(2), 613-632.

Mueller, E., \& Morgan, J.N. (1962). Location decisions of manufacturers. American Economic Review, 52(2), 204-217.

Nanda, R., \& Sørensen, J.B. (2010). Workplace peers and entrepreneurship. Management Science, 56(7), 1116-1126.

Nunn, H.L. (1953). The whole man goes to work: the life story of a businessman. New York: Harper \& Brothers. 
Piore, M.J., \& Sabel, C.F. (1984). The second industrial divide: possibilities for prosperity. New York: Basic Books.

Porter, M.E. (1990). The competitive advantage of nations. New York: Free Press.

Porter, M.E. (2000). Location, competition, and economic development: local clusters in a global economy. Economic Development Quarterly, 14(1), 15-34.

Rivera, M.T., Soderstrom, S.B., Uzzi, B. (2010). Dynamics of dyads in social networks: assortative, relational, and proximity mechanisms. Annual Review of Sociology, 36, 91-115.

Romer, P.M. (1986). Increasing returns and long-run growth. Journal of Political Economy, 94(5), 1002-1037.

Rosenthal, S.S., \& Strange, W.C. (2003). Geography, industrial organization, and agglomeration. Review of Economics and Statistics, 85(2), 377-393.

Ruef, M. (2010). The entrepreneurial group. Princeton: Princeton University Press.

Ruef, M., Aldrich, H.E., Carter, N.M. (2003). The structure of founding teams: homophily, strong ties and isolation among U.S. entrepreneurs. American Sociological Review, 68(2), 195-222.

Saxenian, A. (1994). Regional advantage. Cambridge: Harvard University Press.

Shane, S., \& Cable, D. (2002). Social relationships and the financing of new ventures. Management Science, 48(3), 364-381.

Shane, S., \& Stuart, T.E. (2002). Organizational endowments and the performance of university start-ups. Management Science, 48(1), 154-170.

Sørensen, J.B. (2007). Bureaucracy and entrepreneurship: workplace effects on entrepreneurial entry. Administrative Science Quarterly, 52, 387-412.

Sørensen, J.B., \& Sorenson, O. (2003). From conception to birth: opportunity perception and resource mobilization in entrepreneurship. Advances in Strategic Management, 20, 89-117.

Sorenson, O. (2003). Social networks and industrial geography. Journal of Evolutionary Economics, 13(5), 513-527.
Sorenson, O. (2005). Social networks and the persistence of clusters: evidence from the computer workstation industry. In Breschi, S., \& Malerba, F. (Eds.) Clusters, Networks, and Innovation (pp. 297-316). Oxford: Oxford University Press.

Sorenson, O. (2017). Regional ecologies of entrepreneurship. Journal of Economic Geography, 17(5), 959-974.

Sorenson, O., \& Audia, P.G. (2000). The social structure of entrepreneurial activity: geographic concentration of footwear production in the United States, 1940-1989. American Journal of Sociology, 106(2), 424-462.

Sorenson, O., \& Stuart, T.E. (2001). Syndication networks and the spatial distribution of venture capital investments. American Journal of Sociology, 106(6), 1546-1588.

Sorenson, O., \& Waguespack, D.M. (2006). Social structure and exchange: self-confirming dynamics in Hollywood. Administrative Science Quarterly, 51(4), 560-589.

Stouffer, S.A. (1940). Intervening opportunities: a theory relating mobility and distance. American Sociological Review, 5(6), 845-867.

Stuart, T.E., \& Ding, W.W. (2006). When do scientists become entrepreneurs? American Journal of Sociology, 112(1), 97144.

Stuart, T.E., \& Sorenson, O. (2003). The geography of opportunity: spatial heterogeneity in founding rates and the performance of biotechnology firms. Research Policy, 32(2), 229-253.

Uzzi, B. (1996). The sources and consequences of embeddedness for the economic performance of organizations: the network effect. American Sociological Review, 61(4), 674-698.

von Thunen, J.H. (1966). Isolated state: an English edition of Der isolierte Staat. Oxford: Pergamon.

Weber, A. (1928). Theory of the location of industries. Chicago: University of Chicago Press.

Young, C., \& Lim, C. (2014). Time as a network good: evidence from unemployment and the standard workweek. Sociological Science, 1, 10-27. 